\title{
Studies on the Effect of Fintech on Chinese Economy and Its Development Path
}

\author{
Xin Yang* \\ Business School \\ Nanfang College of Sun Yat-sen University \\ Guangzhou, China
}

\author{
Huiyin Zheng \\ School of Economics \\ Guangzhou College of Commerce \\ Guangzhou, Chin
}

\author{
Xiajun Yi \\ Department of Finance and Economics \\ Guangzhou Vocational and Technical University of Science and Technology \\ Guangzhou, China
}

\begin{abstract}
In recent years, with the continuous development of information science and technology in China, the technique of big data, cloud computing and artificial intelligence have led to the significant development of Fintech in China. Meanwhile, because of the development of the consumption patterns and payment methods in China, the traditional finance industry is unable to meet the current market needs. Therefore, it needs to utilize Fintech to develop Chinese finance industry. From the perspective of Fintech, the present article mainly discussed the influence of FinTech on Chinese economy and the existing shortcomings, and then provided relevant development path of Fintech in the future.
\end{abstract}

Keywords-Chinese Fintech; Development Path; Influence on Economy

\section{INTRODUCTION}

In recent years, the continuous advancement of China's Fintech has shown a staged development. From the advent of Internet finance in 2014 to the current situation, businesses related to Fintech have also rapidly developed, making Fintech being widely used, and attracting much the market attention.

The rapid development of Fintech plays an important role in Chinese economy.

For the financial industry, Fintech can promote the transformation and upgrading of the traditional financial industry. The traditional business is continuously optimized and upgraded, improving the operational efficiency of the financial market, reducing operating costs, and continuously providing new vitality to the financial market.

For the macroeconomic environment, the development of Fintech plays a critical role. China's huge data network and consumer numbers have spurred the technical support of Fintech in various scenarios[1]. For this reason, the future development of Fintech is particularly important.

To study Fintech, first of all, the impact of Fintech on the economy should be the focus. Financial technology has changed the way consumers spend and pay in China. For a long time in the past, Chinese used cash for consumption payment, but now electronic payment had dominated payment in consumption and sometimes in business purchasing. Second, Fintech has changed the development model of the financial industry[2]. Fintech has continuously expanded the financing channels of enterprises and reduced their operating costs. Finally, Fintech has changed China's economic structure. Using various means of financial technology, big data, artificial intelligence and cloud computing, Fintech has continuously innovated the financial industry's business platform to serve more investors.

Through analyzing the current development gaps in China's Fintech, such as imperfect laws and regulations, information security and technological development constraints, the development path of financial technology in the future is mainly concentrated on the legal, regulatory and incentive mechanisms, to continuously improve the sustainability of the development of Fintech. This research idea can comprehensively analyze the development status, prospects and future development path of China's financial technology, and also provide a comprehensive understanding of the development of Fintech. The paper analyzed various issues and laid the theoretical foundation for the development of financial technology.

\section{CURRENT StATUS OF FINTECH IN CHINA}

Fintech first appeared in the United States. It is based on technologies such as big data, cloud computing and artificial intelligence to improve efficiency and promote the development of the financial industry. According to statistics from the Wind database, in 2016, China's Fintech development of China's Fintech presents the following four characteristics:

Based on internet finance, in the early years, the United States, the United Kingdom and other countries with developed financial industries, Fintech appeared earlier. With the advancement of technologies such as big data, cloud computing and artificial intelligence in recent years, the United States has begun to see Fintech company in third-party payment. China's Fintech is based on Internet finance. Since

This work was supported by The Innovative Young Talents Program of Guangdong Province, China (Grant No. 2018WQNCX285) 
2013, China's Internet Company "Big Three" - BAT (Baidu, Alibaba and Tencent) began to compete to carry out financial business with Internet technology. With the continuous development of Internet finance, information security and industry norms have become major issues. Besides, P2P lending and third-party payment services account for a large share of the Chinese financial market.

In recent years, China's Fintech has become a leader in this field and has developed rapidly in a short period of time. According to relevant data, China's Fintech investment and financing growth rate reached 337\%, of which third-party payment is the largest supply in the Fintech field. In the past, Alipay and WeChat were the two payment giants. From the current situation, UnionPay cloud payment and cloud flash payment have also been developed. As of the end of 2015, the growth rate of China's third- party payment sector has exceeded $40 \%$. At the same time, as all walks of life require a large amount of development funds, and Internet crowdfunding continues to develop. In 2015, successful acquisition of funds through Internet crowdfunding has reached 11.424 billion yuan, and this data will continue to climb. The reasons for this phenomenon are mainly the following two aspects:

(1) Fintech makes the investment and financing supply cost low, suitable for the development needs of SMEs, thus attracting a large number of Internet users with capital needs.

(2) The innovation of Fintech has impacted the traditional financial business, changed the supply of the financial industry, and also changed the consumer's consumption habits, so that a large number of consumers feel the convenience brought by Fintech. Taking the Internet "Big Three" - BAT as an example, Baidu develops Baidu wallets and other financial products through its own user resources; Alibaba continues to launch Ant Financial, Huabei, Yu'ebao and YuLibao through Alipay's platform; Tencent Group, through the WeChat user resource platform, built WeChat payment, Tenpay and other Fintech business. It can be seen that the supply of Fintech business in China is increasing.

(3) There is a growing momentum of demand for Fintech. In 2013, Alipay opened the Yu'ebao business. The advent of Yu'ebao has hit the traditional financial industry. On the 18th day of Alipay's launch of the balance treasure business, the absorption of funds has reached 6.6 billion yuan, with online users as many as 2.5 million, and the demand is still rising. In addition to the Yu'ebao business, giants such as Alipay and WeChat continue to innovate in business, launching funds, insurance and loan lending. In all these businesses, the promotions are greater than in the traditional financial industry. Taking the Yu'ebao business as an example, the interest rate is higher than the deposit rate in commercial banks. The field of Fintech has not only been limited to third-party payment, but also closely integrated with consumption in food, clothing, housing and transportation. The giants use the data they have mastered in their e-commerce platforms to firmly grasp the consumer demand and continue to promote the development of Fintech.

(4) The development of Fintech has shown an everexpanding trend. According to the data from Wind database and iResearch, the supply and demand sides of Fintech are constantly expanding. At the same time, the market coverage is also increasing. Fintech has covered the functions of deposit, loan and remittance, and the characteristics of low cost are more in line with the needs of modern society's popular finance. As of 2016, the scale of network fund management has reached 2,746.88 billion yuan, and the scale of online credit funds has reached 1,348.28 billion yuan. Relevant institutions predict that Fintech operating income will continue to grow in the next five years. Businesses such as electronic payment, network fund management and online credit are still rising, and the market capacity and scale of Fintech are still expanding.

\section{THE IMPACT OF FINTECH ON THE MODERN ECONOMY}

Internet finance is the trinity product of the development of the Internet, computer and banking. With the continuous adjustment of industrial structure, Internet finance has gradually developed into Fintech. Fintech has reflected the integration of finance and technology, and it is constantly impacting the development of traditional financial industry[3]. Financial technology, commonly known as "Fintech", is a financial innovation supported by information science and technology. Fintech has a major impact on the traditional economy, mainly reflected in the following three aspects:

\section{A. Fintech changing the traditional way of consumption}

In China, electronic payment has become the preferred payment method. According to statistics, as of 2016, driven by the two major payment giants, Alipay and WeChat, the market size of electronic payment has reached 2.9 trillion US dollars, an increase of about 20 times compared with 2014. At the same time, businesses such as online banking and digital currency have also seen significant growth. Businesses such as "Yuebao", "Huabei" and "LingQianTong" are changing the investment and savings patterns. With the help of big data, cloud computing and artificial intelligence, social networks and e-commerce can calculate consumers' consumption preferences and accurately deliver advertisements to meet the needs of various consumer groups.

\section{B. Fintech changing the operating mode of the traditional financial industry}

The main business of the traditional banking industry is concentrated on deposits, loans, remittances and credit cards. With the continuous development of computer and Internet technologies, online banking and mobile banking have also emerged. As in financing and the advancement of Fintech has brought about network lending and crowdfunding business. Online lending can be divided into P2P network lending and Internet microfinance. P2P network lending is built on the Internet platform, and both the supply and demand sides conduct business transactions through the Internet platform. Internet microfinance refers to the continuous expansion of lending business through the Internet platform. Crowdfunding generally refers to a form of raising funds for the development of a company or for a public good. In 2015, China began to strictly supervise investment and financing financial services such as online lending and crowdfunding. Internet financial companies have been reshuffled, and the quality of the remaining Internet financial companies has also been greatly 
integration of developments in various fields has increased the complexity of Fintech, which has led to an increase in the difficulty of supervision.

\section{B. Reltively simple development of China's Fintech}

In many cases, China's Fintech is built on the business of Internet finance and traditional finance. Therefore, it is an unprecedented challenge for both. However, if Fintech were based only on traditional businesses, the development of

Fintech will be limited. The operating income in the field of China's Fintech mainly comes from the traditional business of Internet finance, that is, the benefits of third-party payment, and this will limit the advancement of Fintech.

\section{A lack of professional talents in China's Fintech field}

Fintech belongs to emerging industries and is developed by means of information science and technology. It requires a large number of professional talents. China's talent cultivation in this field has not yet taken shape. Most of the universities' financial management and financial engineering majors are based on financial courses, mainly to develop financial product development and design capabilities, and rarely involve Fintech. There is a wide gap between international peers. At the same time, Fintech involves information processing such as big data processing, and has high requirements for mathematical statistics.

\section{Lack of effective supervision}

On May 15, 2017, the People's Bank of China announced the formal establishment of the Financial Science and Technology Commission, which aims to strengthen the coordination, leadership and management of China's Fintech work. There are certain advantages in strengthening the selfdiscipline of the industry. China's

Fintech has not yet matured, and laws and regulations have not yet been fully executed. At the same time, the social supervision has not been put in place, and the relevant departments have not yet issued corresponding regulatory policies, which has made the supervision of China's Fintech industry to a certain extent in a blank state. The development of traditional finance and Fintech is fundamentally different. In recent years, the government has continuously introduced relevant laws and regulations of the financial industry. However, due to the particularity of the financial industry, the supervision of China's Fintech is difficult to implement, and various departments are still unable to coordinate. However, the issue of Fintech security has gradually gained the attention of relevant departments.

\section{E. Underdeveloped market environment of China's financial industry}

China's financial market started late, and the financial system has a large gap, which cannot sufficiently meet the needs of Fintech. China's financial market is mainly based on retail investors, who are mainly risk- averse, and the degree of risk acceptance is low. Therefore, in the case of financial market volatility, it is easy to cause systemic risks, which is not conducive to China's Fintech. China's financial market fully developed, and there are large technical risks[4]. The 
Therefore, the government manages the development of supervision is relatively backward, and it is also not healthy for the construction of China's financial science and technology.

\section{The Future DeVElopment PATH OF FinteCH}

Fintech has greatly enhanced the potential of China's consumption sector, and this will be a new development opportunity. In the future, the development of China's Fintech will usher in new breakthroughs[5]. After analyzing the development status and shortcomings, the problems in China's Fintech can be clearly seen. In the future of China's development of Fintech, the government needs to manage from the following three aspects:

\section{A. The role of laws and regulations}

The development of Fintech requires robust laws and regulations as the basis[6]. The government should stipulate corresponding laws and regulations according to the characteristics of each stage of Fintech development as institutional support. At the same time, government departments should formulate different laws and regulations based on the differences in the economic and financial environment in each region, reflecting their individuality and meeting the development needs of the local economy.

\section{B. The role of supervision}

In the financial industry, government regulation plays an important role, directly affecting the operational efficiency and service quality of Fintech. In the development of Fintech, the project should be investigated from the preliminary preparation stage, and the possible loopholes should be identified from the root cause to ensure that the project can meet relevant requirements during construction. Simultaneously, in Fintechrelated industries, government departments also impose supervision, under the principle of self-discipline in the industry, to foster a good social atmosphere, guide innovative supervision methods, reduce supervision costs, and finally form a new regulatory system that belongs to China's Fintech industry.

\section{The role of incentive mechanism}

Since Fintech is based on technologies such as big data, cloud computing and artificial intelligence, it is related to intellectual property issues. The government should strengthen the management of properties to ensure that IP in this area can be effectively protected. The government must create a suitable environment for all financial participants, thus mobilizing the positive enthusiasm of all parties. For enterprises that contribute to the development of the Fintech industry, the government should provide relevant incentives and preferential policies to ensure the vitality of Fintech development.
China's Fintech, and from different perspectives, this will guarantee advancement. Using incentive regulation to mobilize the enthusiasm of social capital, the government must protect property rights in the construction and operation process from infringement, which will mobilize social capital with a clear reward and punishment method, and promote the optimal allocation of resources for social capital. This also enables the optimal allocation of social resources, ensuring the economic and social benefits of all participants. Therefore, in the future of China's Fintech, the way of government regulation should be studied. The government should constantly improve the relevant regulatory methods, adapt to the development needs of the times, to meet the development mode in different economic environments, so that this model can be of China characteristics.

\section{SUMMARY}

With the rapid rise of Fintech around the world, it has attracted widespread attention from governments and financial institutions. Therefore, the tide of Fintech development is unstoppable, exploring its impact on China's economy, how to improve Fintech services and regulatory models, and achieving a balance between safety and efficiency will benefit FinTech's healthy growth in China. This paper analyzed the status of China's Fintech and discussed the impact of Fintech on China's economy and residents' lives. It is known that China's Fintech industry is at the initial stage of development, and various constructions are still being explored. At the same time, in the process of construction, there are also various kinds of problems. Finally, from the perspective of laws, regulations, supervision and incentives, the development path of China's Fintech is proposed.

\section{REFERENCES}

[1] G.F. Sun. The current situation, prospect and policy suggestions of China's consumer finance[J]. Finance Forum. 2018(02) (In Chinese)

[2] R. Weber, Back to the (Technology) Future. Journal of Financial Service Professionals 70, 2016, pp. 42-45.

[3] X.R. Yi, The connotation, essence and future development of financial science and technology--General analysis based on financial theory, [J]. Jianghai Academic Journal. 2017(02). (In Chinese)

[4] Y. Zhao. Study on the characteristics, rise, function and risk of Fintech[J].Finance Regulation Research, 2016(09):57-70. (In Chinese)

[5] D. Wang. Discuss the competition pattern of global financial technological innovation and China's innovation strategy[J]. International Finance Research. 2018(12) (In Chinese)

[6] J.H. Li, Development and Regulation of Fintech, [J]. Times Finance, 2018(1):65-66. (In Chinese) 